\title{
PERENCANAAN RUANG TERBUKA HIJAU PADA PUNGGUNG BUKIT KELURAHAN PASIR PANJANG KOTA KUPANG
}

\begin{abstract}
SUSANA SURATAMA
Anstrak : Ruang Terbuka Hijau (RTH) pada punggung bukit Kelurahan Pasir Panjang Kota Kupang sebagai bagian dari ruang terbuka belum mendapat perhatian yang memadai dalam pembangunannya. Hal ini dapat terlihat dari belum adanya rencana dan pedoman dalam kegiatan pembangunan sebuah RTH dan sering terjadi alih fungsi lahan RTH untuk kegiatan yang lebih menguntungkan dari sisi ekonomis. Di sisi lain kelurahan Pasir Panjang kota Kupang terus berkembang akibat dinamika aktivitas kota baik fisik maupun non fisik, sementara luasan lahan kota secara administrativ tetap sehingga konflik penggunaan dan pemanfaat ruang dapat terjadi dan dikhawatirkan akan mengorbankan fungsi-fungsi ruang yang dinilai tidak ekonomis bagi perkembangan kota seperti RTH kota. Penelitian ini bertujuan merumuskan konsep-konsep dalam perencanaan ruang terbuka hijau yang sesuai dengan kondisi kelurahan Pasir Panjang kota Kupang yang beriklim tropis yang dapat menjadi pedoman pembangunan kota Kupang selanjutnya, khususnya dari aspek penataan ruang kota yang seimbang dan memperhatikan kondisi lingkungan alam. Penelitian ini mengkajian prinsip normatif perancangan RTH kota akan dipakai untuk membantu merumuskan prinsip tersebut dengan memperhatikan hasil observasi di lapangan mengenai kondisi kelurahan Pasir Panjang kota Kupang dan hasil wawancara dengan beberapa nara sumber. Hasil studi menunjukkan bahwa kelurahan Pasir Panjang Kota Kupang mempunyai kondisi RTH yang belum tertata, baik. Sementara dari segi luasan masih memenuhi syarat dan masih banyak lahan kosong berupa semak belukar serta padang rumput yang dapat dimanfaatkan menjadi salah satu potensi pemenuhan RTH. Memperhatikan kondisi kelurahan Pasir Panjang kota Kupang, maka konsep-konsep perencanaan RTH kota adalah RTH yang multifungsi dengan dua tujuan utama yaitu membantu mengatur iklim mikro kota dan menjaga tata hidrologi. Iklim mikro kota yang lebih sejuk dan nyaman dicapai dengan persebaran RTH dan pemilihan vegetasi yang tepat. Sementara untuk menjaga sistem tata hidrologi dicapai dengan adanya RTH kawasan lindung pada punggung bukit di kelurahan Pasir Panjang Kota Kupang.
\end{abstract}

Kata kunci: Ruang Terbuka Hijau, Punggung Bukit Kelurahan Pasir Panjang, Iklim Tropis, Perencanaan.

\section{PENDAHULUAN}

Ruang Terbuka Hijau (RTH) sebagai bagian dari tata ruang kota masih dianggap sebagai lahan yang tidak efisien atau tanah cadangan untuk membangun struktur kota. RTH kota masih merupakan lahan sisa yang setiap saat dapat berubah fungsi sesuai perkembangan dan pertumbuhan kota. Hal ini terjadi karena tingginya nilai tanah, sehingga setiap bidang tanah diupayakan seproduktif mungkin untuk 
mencapai optimalisasi ekonomi.

Berkurangnya RTH Kota secara bertahap akan mengakibatkan degradasi lingkungan, terutama di kota - kota besar sehingga menimbulkan dampak buruk terhadap kehidupan kota. Beberapa contoh tersebut seperti tingginya tingkat polusi udara pencemaran air minum, kekeringan, panasnya suhu udara, gangguan suara dan lainnya. Sementara kehadiran RTH penting bagi kesehatan, kesejahteraan, kenyamanan dan keamanan penduduk kota. Peran Ruang Terbuka Hijau Kota adalah mengatur suhu udara kota, meningkatkan kelembaban udara, mengurangi kecepatan angin, mengurangi pencemaran udara, meredam kebisingan dan melindungi sistem tata air.

Dalam beberapa tahun terakhir ini dapat kita katakan bahwa pembangunan kota Kupang cukup pesat. Kondisi ini akan semakin berkembang pada periode di tahun-tahun mendatang. Akan tetapi di sisi lain majunya pembangunan di wilayah perkotaan tidak diimbangi dengan penyediaan produk rencana penataan ruang pada kawasan perkotaan.

Kelurahan Pasir Panjang yang merupakan salah satu dari 10 Kelurahan yang berada di Kecamatan Kota Lama Kota Kupang telah mengalami pertambahan penduduk yang cukup pesat, dengan luasan daerahnya adalah 62 HA mempunyai jumlah penduduk pada tahun 2011 yaitu berjumlah: 6.069 jiwa yang terdiri dari $1.158 \mathrm{KK}$ (kepala keluarga) Sehingga rata-rata perkeluarga: 5 jiwa.

Permasalahan selanjutnya akan menjadi pertanyaan penelitian dan diupayakan untuk dicari jawaban pemecahannya, adalah :

1. Bagaimana kondisi Ruang Terbuka Hijau yang ada di Punggung Bukit Kelurahan Pasir Panjang Kota Kupang ?

2. Berdasarkan kondisi karakteristik yang ada bagaimana konsep perencanaan Ruang Terbuka Hijau pada Punggung Bukit Kelurahan Pasir Panjang Kota Kupang ?
Tujuan dilaksanakan penelitian ini, adalah untuk : 1). Mendeskripsikan kondisi Ruang Terbuka Hijau yang ada di Punggung Bukit daerah Kelurahan Pasir Panjang Kota Kupang; dan 2). Mendeskripsikan konsep perencanaan Ruang Tebuka Hijau di daerah Punggung Bukit Kelurahan Pasir Panjang Kota Kupang.

\section{METODE PENELITIAN}

Lokasi penelitian Perencanaan Ruang Terbuka Hijau Pada Punggung Bukit di Kelurahan Pasir Panjang Kota Kupang di Provinsi Nusa Tenggara Timur yaitu di Kecamatan Kota Lama Kelurahan Pasir Panjang. Kelurahan Pasir Panjang merupakan salah satu dari 10 kelurahan yang berada dalam Kecamatan Kota Lama Kota Kupang. Kelurahan Pasir Panjang terletak 100 $m$ dari garis pantai Teluk Kupang dalam kawasan areal pemukiman yang telah tertata sesuai prosedur area pengembangan pemukiman perumahan Tata Kota. Luas wilayah kelurahan Pasir Panjang adalah $62 \mathrm{Ha}$.

\section{Variabel Penelitian}

Analisis dilakukan melalui 3 tahapan yaitu mengidentifikasi potensi dan permasalahan yang terdapat pada RTH kelurahan Pasir Panjang, pendapat para pelaku pembangunan yang kompeten, dan perumusan strategi perencanaan berupa identifikasi prinsip normatif perancangan RTH kota.

Untuk mengetahui gambaran aspek fisik maupun sosial yang nampak di lokasi permukiman yang dibangun tidak sesuai peruntukannya pada Kelurahan Pasir Panjang, Kecamatan Kota Lama Kota Kupang, maka variabel yang menjadi fokus pada penelitian ini adalah sbb:

- Pengertian, fungsi dan manfaat RTH

- Identifikasi prinsip perencanaan RTH

\section{Jenis Penelitian}

Berdasarkan permasalahan, tujuan dan 
sasaran yang ingin dicapai, maka penelitian ini menerapkan studi deskriptif dan eksploratif. Penelitian ini menjelaskan gambaran keadaan nyata yang ada di lapangan, lalu menjabarkan ke dalam fakta dan persoalan yang dihadapi. Kemudian dengan memperhatikan prinsip normatif Konsep Perencanaan Ruang Terbuka Hijau pada Kelurahan Pasir Panjang Kota Kupang, dan pendapat dari narasumber, persoalan dianalisis untuk mencapai tujuan dari konsep penanganan atau perancangan yang ditetapkan sehingga dihasilkan prinsip-prinsip pengelolaan dan perancangan Ruang Terbuka Hijau yang sesuai dengan kondisi Kelurahan Pasir Panjang Kota Kupang.

Penelitian ini dilakukan juga pada masyarakat yang bermukim di Kelurahan Pasir Panjang Kecamatan Kota Lama Kota Kupang, oleh sebab itu penulis mencoba memberikan gambaran tentang pendapat dan pemahaman dari warga kelurahan Pasir Panjang tentang fungsi Ruang Terbuka Hijau di Kelurahan Pasir Panjang Kota Kupang.

Teknik pengumpulan data yang akan dilaksanakan terdiri dari, pengumpulan data sekunder dan data primer.

- Pengumpulan data sekunder berupa datadata normativ yang bersumber dari penelusuran dokumen-dokumen (survey literatur) yang telah ada sebelumnya, berupa sejarah perkembangan kondisi lokasi penelitian, gambaran umum kondisi lokasi penelitian, arahan penggunaan ruang sesuai arahan pada dokumen Rencana Umum Tata Ruang yang telah dilakukan sebelumnya dan review yang telah dilakukan terhadap dokumen Rencana Umum Tata Ruang beserta dokumen rencana detail dan rencana teknis yang telah ada.

- Data primer dikumpulkan melalui survey langsung ke lokasi RTH, bangunan rumah tinggal dan prasarana maupun sarana, untuk melihat secara langsung kondisi, maupun ketersediaan prasarana dan sarana yang terdapat pada lokasi penelitian dan dilakukan pengamatan sesuai variabel yang diamati.

Analisa data yang dilakukan dalam penelitian ini, dilaksanakan dengan cara :

- Data hasil pengamatan atau observasi lapangan, wawancara, rekaman foto dan kuisioner sesuai kondisi eksisting selanjutnya dilakukan analisis Deskriptif di bawah paradigma Kualitatif, dengan cara berpikir induktif yaitu dengan metode analisa data yang spesifik dari lapangan dianalisis dan ditafsirkan untuk mengetahui maksud serta maknanya, kemudian dihubungkan dengan masalah penelitian. Analisa data dimulai dengan menelaah seluruh data yang tersedia dari berbagai sumber, yaitu dari wawancara dan pengamatan lapangan yang sudah ditulis dalam catatan lapangan dan hasil rekaman dokumentasi. Setelah dipelajari dan ditelaah maka langkah berikutnya adalah mengadakan reduksi data yang dilakukan dengan jalan membuat abstraksi yang dituangkan kedalam catatan refleksi. Abstraksi merupakan usaha membuat rangkuman inti, proses dan pernyataan-pernyataan yang perlu dijaga sehingga tetap berada di dalam kondisi sesuai keadaan di lokasi penelitian.

\section{HASIL DAN PEMBAHASAN \\ Gambaran Umum Kelurahan Pasir \\ Panjang Kota Kupang}

Luas wilayah kelurahan Pasir Panjang adalah $62 \mathrm{Ha}$, yang terdiri dari enam (6) kelompok Rukun Wilayah (RW), Sembilan belas (19) kelompok Rukun Tetangga (RT), Jumlah Penduduk : 6.069 jiwa, Jumlah KK (Kepala Keluarga: 1.158 KK dan Jumlah bangunan : 867 bangunan. (Laporan Bulanan Kelurahan Pasir Panjang, Maret 2011). 
Dari hasil pengamatan lapangan terhadap kondisi RTH Kelurahan PasirPanjang kota Kupang, maka luasan RTH yang ada mencapai $28,535 \mathrm{Ha}$ atau $46,024 \%$. Kawasan fungsional yang terdapat pada kelurahan Pasir Panjang kota Kupang memiliki KDB rata - rata $70 \%$ sehingga $30 \%$ difungsikan untuk RTH maka luasan RTH dapat dihitung sebagai berikut :

Tabel. Luasan RTH pada kelurahan Pasir Panjang Kota Kupang

\begin{tabular}{|c|c|c|c|}
\hline No. & $\begin{array}{l}\text { Penggunaan } \\
\text { Lahan }\end{array}$ & $\begin{array}{l}\text { Luas } \\
\text { (Ha) }\end{array}$ & RTH \\
\hline I & $\begin{array}{l}\text { Kawasan } \\
\text { Terbangun }\end{array}$ & & \\
\hline 1 & Permukiman & 39,05 & 11,71 \\
\hline 2 & Perdagangan & 1,5 & 0,45 \\
\hline 3 & Pemerintahan & 4,2 & 1,26 \\
\hline 4 & Pendidikan & 2,4 & 0,72 \\
\hline \multirow[t]{2}{*}{5} & Peribadatan & 0,65 & 0,195 \\
\hline & Sub Total & 47,8 & 14,335 \\
\hline II & $\begin{array}{l}\text { Kawasan Belum } \\
\text { Terbangun }\end{array}$ & & \\
\hline 1 & Kuburan & 0,7 & 0,7 \\
\hline 2 & Semak Belukar & 4,2 & 4,2 \\
\hline 3 & Jalur Hijau & 6,8 & 6,8 \\
\hline \multirow[t]{3}{*}{4} & $\begin{array}{ll}\text { Pasir } & \text { (pesisir } \\
\text { pantai) }\end{array}$ & 2,5 & 2,5 \\
\hline & Sub Total & 14,2 & 14,2 \\
\hline & Total I + II & 62 & 28,535 \\
\hline
\end{tabular}

Sumber : Hasil survey, 2011

Hasil perhitungan didapat luasan RTH kelurahan Pasir Panjang kota Kupang seluas $28,535 \mathrm{Ha}$ atau $46,024 \%$ dari luas wilayah kelurahan.

\section{Lokasi Ruang Terbuka Hijau}

Hasil Identifikasi Ruang Terbuka Hijau di Kelurahan Pasir Panjang Kota Kupang
Tabel. Distribusi RTH di Kelurahan Pasir Panjang Kota Kupang

\begin{tabular}{|c|c|c|c|}
\hline No. & JENIS & KOXDISI & KELEMAHAN \\
\hline 1 & $\begin{array}{l}\text { Kawasan Tebing } \\
\text { /Punggung Bukit. } \\
\text { (sepanjang } \\
\text { punggung bukit } \\
\text { Pasir Panjang) }\end{array}$ & $\begin{array}{l}\text { Luas: } 4 \text { ha } \\
\text { Lokasi } \\
\text { RT11/RW04, } \\
\text { RT09/RW05 } \\
\text { Vegetasi : } \\
\text { semak belukar } \\
\text { Fungsi : } \\
\text { Perlindungan } \\
\text { kawasan tebing. }\end{array}$ & $\begin{array}{l}\text { - Penataan lahan yang } \\
\text { kurang optimal dan tidak } \\
\text { terawat dengan baik } \\
\text { - Pengaihfungsian lahan } \\
\text { menjadi lahan terbangun } \\
\text { - Kurang optimalnya fungsi } \\
\text { kawasan hijau dan } \\
\text { bentang alam } \\
\text { - Keterbatasan pemerintah } \\
\text { dalam pengelolaan dan } \\
\text { pengendalian kawasan ini. } \\
\text { - Schagian hesar lahan } \\
\text { dikelola oleh masyarakat } \\
\text { dan kurang menyadari } \\
\text { tentang perlunya ruang } \\
\text { terbuka hijan publik dalam } \\
\text { lingkungan. }\end{array}$ \\
\hline 2 & Taman Ina Boi & $\begin{array}{l}\text { Luas : } 1.200 \mathrm{~m}^{2} \\
\text { Lokasi : RT } 11 / \\
\text { RW } 04 \\
\text { Vegetasi: Pohon } \\
\text { Tuak, Angsana, } \\
\text { Bougenville. } \\
\text { Fungsi : Ruang } \\
\text { terbuka publik, } \\
\text { rckrcasi. }\end{array}$ & $\begin{array}{l}\text { - Pemanfaatan taman kota } \\
\text { yang belum optimal. } \\
\text { - Komponen - komponen } \\
\text { taman yang sangat rentan } \\
\text { terhadap perusakan oleh } \\
\text { para pengguna taman dan } \\
\text { terkena polusi udara } \\
\text { kendaraan. } \\
\text { - Kondisi vegctasi yang } \\
\text { belum sesuai dengan iklim } \\
\text { kota Kupang. } \\
\text { - Pemeliharaan dan } \\
\text { pengawasan masih sangal } \\
\text { terbatas schimgga perlu } \\
\text { perhatian pemerintah. }\end{array}$ \\
\hline 3 & $\begin{array}{ll}\text { Tamann } & \text { Pasir } \\
\text { Panjang } & \\
\text { (Subasuka dan } \\
\text { sekitarnya) }\end{array}$ & $\begin{array}{l}\text { Luas : } 3.000 \mathrm{~m}^{2} \\
\text { Lokasi : RT 07/ } \\
\text { RW 03 } \\
\text { Vegetasi } \\
\text { Gamal, Angsana } \\
\text { Fungsi : Tempat } \\
\text { relreasi. }\end{array}$ & $\begin{array}{l}\text { - Teriadi perubahan fungsi } \\
\text { lahan menjadi lahan } \\
\text { terbangun. } \\
\text { - Pemanfaatan taman kota } \\
\text { yang belum optimal. } \\
\text { - Kondisi vegetasi yang } \\
\text { belum sesuai dengan iklim } \\
\text { kota Kupang. } \\
\text { - Belum adanya acuan yang } \\
\text { digunakan dalam } \\
\text { perencanaan dan desain } \\
\text { laman kota, dan perlu } \\
\text { adanya perhatian yang } \\
\text { optimal dari pemerintah } \\
\text { kota. }\end{array}$ \\
\hline
\end{tabular}




\begin{tabular}{|c|c|c|c|}
\hline 4 & $\begin{array}{l}\text { Lapangan } \\
\text { Olahraga Taman } \\
\text { Ria }\end{array}$ & $\begin{array}{l}\text { Luas : } 2.400 \mathrm{~m}^{2} \\
\text { Lotasi: RT } 07 \text { / } \\
\text { RW 05 } \\
\text { Vegetasi : - } \\
\text { Fungsi } \\
\text { Olahraga, } \\
\text { Retreasi. }\end{array}$ & $\begin{array}{l}\text { - Tidak terpenuhinya fungsi } \\
\text { hijau pada lapangan } \\
\text { olahraga yang ada } \\
\text { - Penataan dan perawatan } \\
\text { yang tidak optimal dan } \\
\text { kurang adanya perhatian } \\
\text { dar pemerintah Kota } \\
\text { - Fasilitas pendukung yang } \\
\text { tidak memadai } \\
\text { - Kurangnya kesadaran } \\
\text { masyarakat dalam } \\
\text { menjaga fasilitas yang } \\
\text { tersedia. }\end{array}$ \\
\hline 5 & $\begin{array}{l}\text { Kawasan } \\
\text { Pemakaman } \\
\text { (Taman Makam } \\
\text { Pahlawar } \\
\text { Dharmaloka) }\end{array}$ & $\begin{array}{l}\text { Luas : } 7.000 \mathrm{~m}^{2} \\
\text { Lotasi : RT 04/ } \\
\text { RW 02 } \\
\text { Vegetasi } \\
\text { Kamboja, } \\
\text { Bougenvile } \\
\text { Fungsi } \\
\text { Penakaman } \\
\text { Pahlawan }\end{array}$ & $\begin{array}{l}\text { - Belum adanya standar } \\
\text { perataan yang menjadi } \\
\text { acuan dalam } \\
\text { menfungsikan lahan } \\
\text { penakaman sebagai RTH, } \\
\text { peru perhatian } \\
\text { Penerintah Kota } \\
\text { - Pemilihan vegetasi yang } \\
\text { belum optimal sehingga } \\
\text { belum terpenuhinya fungsi } \\
\text { hijau pada area } \\
\text { penakaman. }\end{array}$ \\
\hline 6 & $\begin{array}{l}\text { Kawasan } \\
\text { Sempadan Pantai } \\
\text { (sipanjarg pantai } \\
\text { Teluk Kupang) }\end{array}$ & $\begin{array}{l}\text { Luas : } 2,5 \text { ha } \\
\text { Lolasi } \\
\text { RT07/RW03, } \\
\text { RT03/RW01, } \\
\text { RT13/RW05 } \\
\text { Vegetasi : } \\
\text { Polon Tuak, } \\
\text { Kelapa, } \\
\text { Kusambi, } \\
\text { Mangrove. } \\
\text { Gamal, Semak } \\
\text { bel.kaar. } \\
\text { Fungsi } \\
\text { Perlincuncan } \\
\text { kawasana } \\
\text { ekcsistem } \\
\text { Pantai. }\end{array}$ & $\begin{array}{l}\text { - Pengalihfungsian } \\
\text { sempadan menjadi lahan } \\
\text { tertangun } \\
\text { - Luasan yang semakin } \\
\text { bersurang } \\
\text { - Perranfaatan yang merusak } \\
\text { sunberdaya alam yang } \\
\text { ada } \\
\text { - Beum adanya perhatian } \\
\text { pemerintah dalam } \\
\text { mengelola wilayah ini. }\end{array}$ \\
\hline
\end{tabular}

Sumber: Data Priner, 2011

Hasil Analisa Perencanaan RTH di Punggung Bukit Kelurahan Pasir Panjang Kota Kupang Jenis RTH

\section{Jalur Hijau Jalan}

Komponen :

\section{a. Vegetasi}

Prinsip Perencanaan : Fungsi jalur hijau adalah memberikan keteduhan dan kenyamanan bagi pengguna jalan, membantu menciptakan iklim mikro dan menyerap polusi dan kendaraan, Dominasi vegetasi pada jalur hijau jalan secara linear pada sempadan jalan dan median jalan dengan luas sekitar $80 \%$ dari luas lahan sempadan dan media jalan yang ada, Karakter vegetasi adalah tinggi, daun rapat, hijau sepanjang tahun, tidak mudah rapuh dan patah, vegetasi tahunan, kerapatan renggang, Jenis vegetasi adalah Pohon Kayu Merah (Pterocapus indiscus), pohon jati (Swetenia mahagoni), Gmelina Sp, Golongan Polythia longifolia, Evergreen, Kenanga (Cananga odorata), lontar.

\section{b. Tanda (Signage)}

Prinsip Perencanaan : Penempatan penanda tidak menghalangi pandangan pejalan dan pengendara dan tidak saling tumpang tindih, Informasi harus singkat, jelas dan sarat makna seperti kata, logo, warna untuk menghindari kesalahan informasi serta dapat juga dipergunakan oleh para penyandang cacat, Desain penanda berkaitan dengan pola tulisan dan warna yang jelas, ketinggian yang tepat, material yang murah, mudah dan kuat.

\section{c. Konstruksi Perlindungan}

Prinsip Perencanaan : Konstruksi perlindungan diterapkan pada kawasan-kawasan jalan yang rawan bencana seperti erosi, Pemilihan jenis konstruksi mempertimbangkan lokasi, fungsi dan jangka waktu perlindungan yang dapat diberikan pada area atau kawasan yang akan dilindungi, Desain dibuat sederhana sehingga mudah dilaksanakan tapi tetap kuat, Bahan-bahan konstruksi perlindungan dapat memakai bahan alam dan buatan seperti vegetasi, batu karang, tembok, beton, baja dan sebagainya.

\section{d. Pengelolaan}

Prinsip Perencanaan : Pengelolaan diupayakan dikelola oleh swasta dan masyarakat

- Perlu ada pedoman dan paduan dalam kegiatan pengelolaan 


\section{Kawasan Tebing}

Komponen :

\section{a. Vegetasi}

Prinsip Perencanaan : Fungsi kawasan lindung konservasi adalah melindungi sistem tata air dengan membantu meresapkan air hujan dalam tanah (air tanah), fungsi lainnya adalah mengatur iklim mikro, perlindungan flora dan fauna, Kawasan lindung konservasi perlu dominasi vegetasi $100 \%$ dari luas lahan.

\section{b. Konstruksi Perlindungan}

Prinsip Perencanaan : Konstruksi perlindungan diterapkan pada daerah yang rawan bencana seperti erosi / longsor, pemilihan jenis konstruksi mempertimbangkan lokasi, fungsi dan jangka waktu perlindungan yang dapat diberikan pada area atau kawasan yang akan dilindungi, bahan-bahan konstruksi perlindungan dapat memakai bahan alam dan buatan seperti vegetasi, batu karang, tembok, beton, baja dan sebagainya. Namun diutamakan dari vegetasi seperti penanaman tanaman Gamal dan Lamtoro yang berfungsi sekaligus sebagai tanaman pionir

\section{c. Pengelolaan}

Prinsip Perencanaan : Pengelolaan diupayakan dikelola oleh swasta dan masyarakat, perlu ada pedoman dan paduan dalam kegiatan pengelolaan.

\section{SIMPULAN, SARAN DAN IMPLIKASI Simpulan}

Berdasarkan hasil penelitian maka dapat diambil kesimpulan sebagai berikut :

1. Ruang Terbuka Hijau (RTH) pada Punggung Bukit kelurahan Pasir Panjang Kota Kupang menghadapi sejumlah permasalahan mulai dari aspek pengelolan, perencanaan, teknis, regulasi, anggaran, pengelolaan dan partisipasi masyarakat. Aspek perencanaan berkaitan dengan belum adanya arahan rencana yang lebih detail seperti rancangan khusus RTH Kota, pedoman dan termasuk belum adanya master plan RTH Kota. Untuk dapat mengatasi kondisi Kelurahan Pasir Panjang Kota Kupang yang beriklim tropis yang panas dan kering hampir sepanjang tahun maka dilakukan dengan menyusun rumusan - rumusan konsep pengelolaan dan perancangan RTH kota. Luas RTH kelurahan Pasir Panjang Kota Kupang secara garis besar masih memenuhi syarat dengan lahan yang tersedia seluas 28,535 $\mathrm{Ha}$ atau $46,024 \%$ dari luas wilayah kelurahan.

2. Konsep perencanaan Ruang Terbuka Hijau pada pada kelurahan Pasir Panjang kota Kupang dianalisa berdasarkan komponen komponen sebagai berikut :

Prinsip Lingkungan Fisik yang meliputi : vegetasi, tanah, air.

Prinsip Sarana meliputi : pedestrian, jalur kendaraan, parkir terbuka, bangunan penunjang, tanda (signage), ruang terbuka, perlengkapan lanskap, jaringan utilitas.

Prinsip Pengelolaan dan Perancangan meliputi : konstruksi perlindungan, pengelolaan, penggunaan.

Prinsip pengelolaan dan perancangan RTH kelurahan Pasir Panjang Kota Kupang secara khusus yaitu: Tipologi Ruang Terbuka Hijau Kota yang dapat dikembangkan terdiri dari RTH publik dan RTH privat. RTH publik terdiri dari taman kota, lapangan terbuka/olahraga, jalur hijau jalan, sempadan pantai, dan daerah tebing kawasan lindung konservasi.

\section{REKOMENDASI}

1. RTH pada Punggung Bukit di kelurahan PasirPanjang Kota Kupang perlu mendapat perhatian dari Pemerintah Kota Kupang dan dirancang serta dikelola dengan memperhatikan karakter lokal seperti kehadiran vegetasi khas lokal setempat dan vegetasi yang sesuai dengan kondisi kota Kupang.

2. Dominasi vegetasi dalam RTH kelurahan 
Pasir Panjang kota Kupang sangat menentukan dalam keberhasilan fungsi RTH sebagai pengatur iklim mikro kota dan menjaga keseimbangan hidrologis. Dominasi vegetasi lebih khusus pada kawasan seperti sempadan pantai dan kawasan konservasi.

3. Ruang Terbuka Hijau pada kelurahan Pasir Panjang kota Kupang diharapkan mempunyai daya tarik yang kuat sebagai landmark kota dengan vegetasi yang khas. Taman - taman kota sebagai bagian dari RTH dikembangkan sebagai taman yang multifungsi sebagai fungsi pengatur iklim mikro, tata hidrologi kota dan berfungsi juga sebagai tempat rekreasi, sosialisasi publik, pameran dan paru-paru kota.

\section{DAFTAR PUSTAKA}

Dirjen Penataan Ruang. PU. 2006. RTH Sebagai Unsur Utama Tata Ruang Kota. Jakarta.

Drabkin, Darin. 1977. Land Policy and urban Growth. Pergamon Press.

Gie. 1982. The Liang Ensiklopedi Administrasi.

PT. Gunung Agung. Jakarta.

Howard, E. 1965. Garden Cities of Tomorrow.

Faber and Faber Ltd. London.

Irwan, Z.D. 2005. Tantangan Lingkungan dan Lansekap Hutan Kota, PT. Bumi Aksara. Jakarta.

Karyono, T.H. 2005. Seputar permasalahan Arsitektur Kota Tropis Dunia Ketiga. CV

\section{Tehaka Arkita.}

Laurie, I.C. 1979. Nature in Cities. The natural Environment in the Design and Development of Urban Green Space, John Wiley $\&$ Sons. New York.

Kecamatan Kelapa Lima Dalam Angka 2009. BPS Kota Kupang.

Kupang Dalam Angka 2009-2010, BPS Kota Kupang.

Laporan Bulanan Kelurahan Pasir Panjang Bulan Maret 2011. Kota Kupang.

Pedoman Cipta Karya PU Tahun 1987 tentang Petunjuk Perencanaan Kawasan Perumahan Kota.

Rencana Tata Ruang Wilayah (RTRW) Kota Kupang 2005-2015. Bapedda Kota Kupang.

\section{Peraturan:}

Peraturan Pemerintah Nomor 63 Tahun 2002 tentang Hutan Kota.

Peraturan Pemerintah Nomor 26 Tahun 2008 tentang Rencana Tata Ruang Wilayah Nasional.

Perda Nomor 7 Tahun 2006 tentang Ruang Terbuka Hijau di Kota Kupang.

Permendagri Nomor 1 Tahun 2007 tentang Penataan Ruang Terbuka Hijau Kawasan Perkotaan.

Undang - Undang No. 26 Tahun 2007 tentang Penataan Ruang, Fokusmedia. Bandung 2007. 


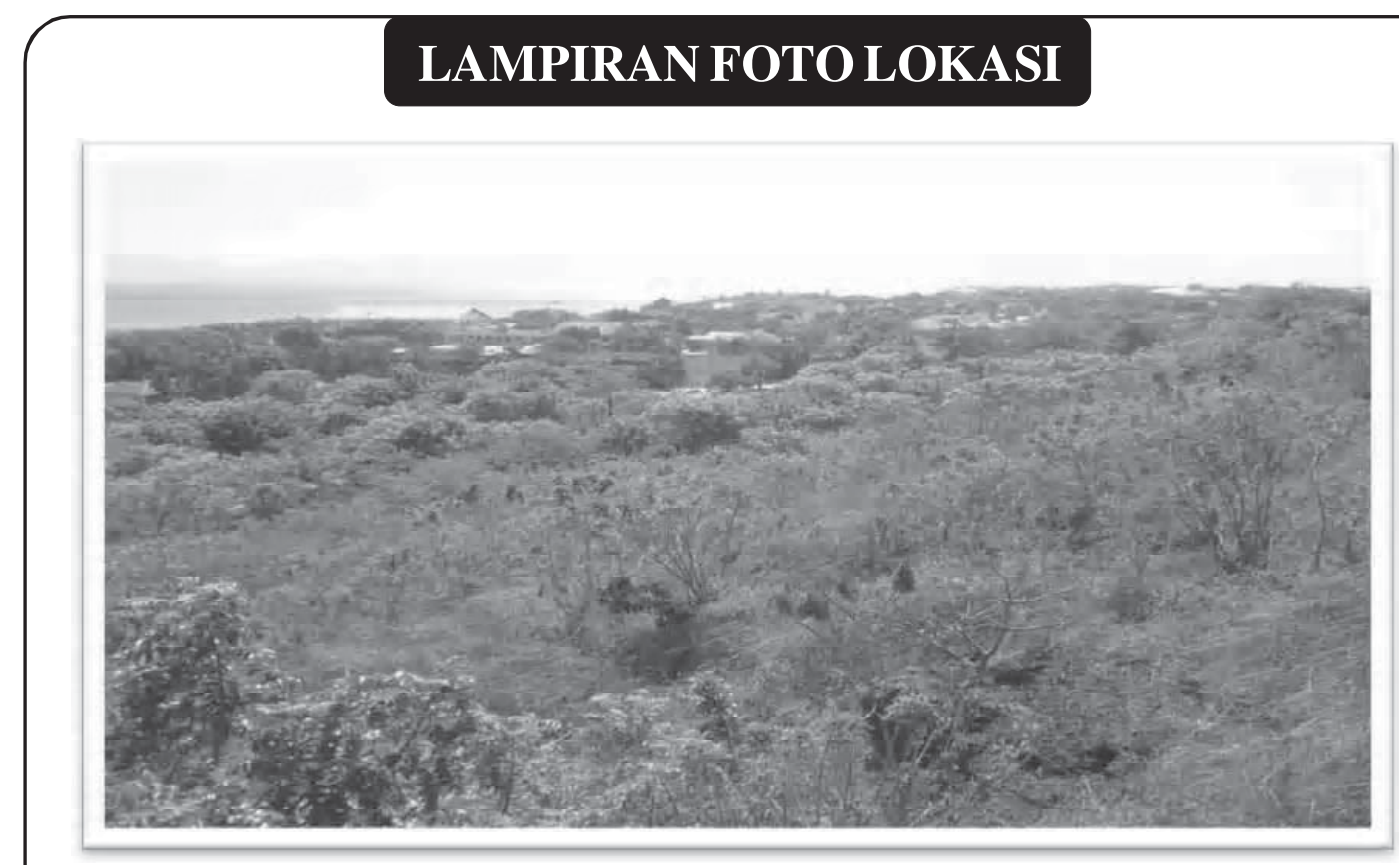

Gambar 01. Semak belukar pada RTH di Punggung Bukit Kelurahan Pasir Panjang Kota Kupang, yang belum mendapat perhatian khusus. Lokasi: RT.11/RW.04 Kelurahan Pasir Panjang.

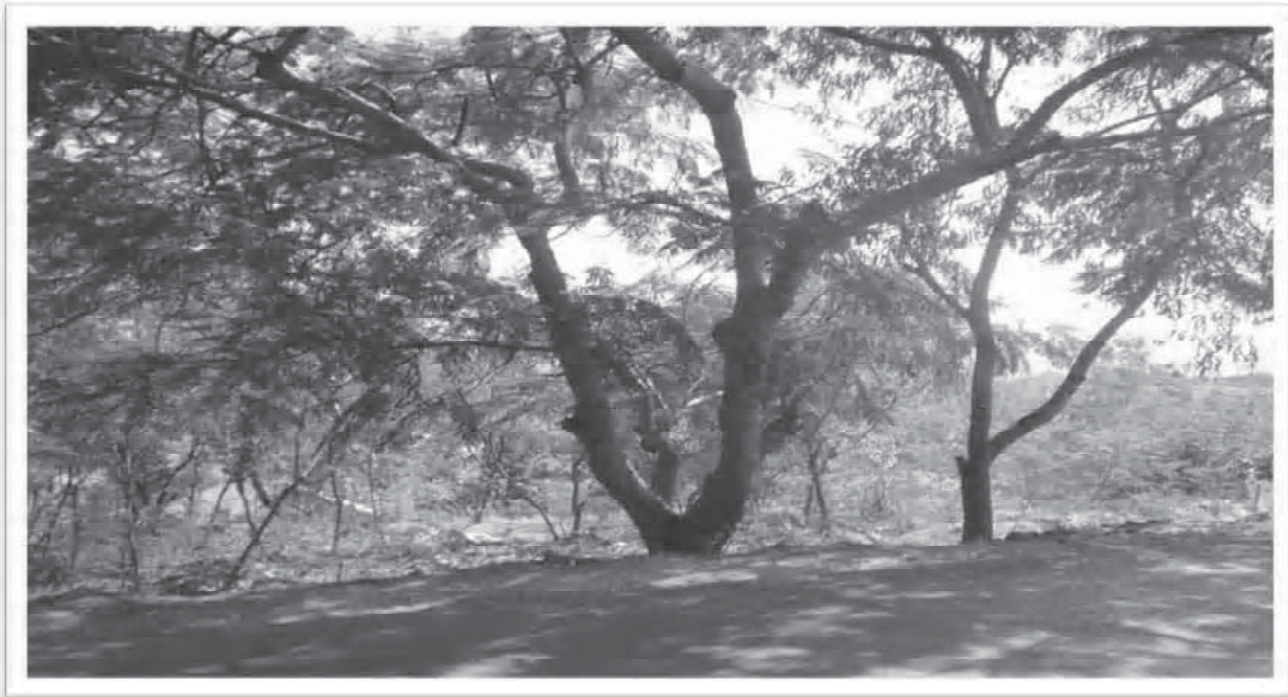

Gambar 02. Jalur Hijau di lokasi : RT08/RW03. Pada kawasan tebing, punggung bukit Kelurahan Pasir Panjang Kota Kupang. 